\title{
CONDITIONING A PROCESS-BASED MODEL OF SEDIMENTARY ARCHITECTURE TO WELL DATA
}

\author{
DEREK KARSSENBERG ${ }^{1}$, TORBJÖRN E. TÖRNQVIST ${ }^{2}$, AND JOHN S. BRIDGE ${ }^{3}$ \\ ${ }^{I}$ The Netherlands Centre for Geo-ecological Research (ICG), Faculty of Geographical Sciences, Utrecht University, P.O. Box 80115, 3508 TC Utrecht, The Netherlands \\ e-mail: d.karssenberg@geog.uu.nl \\ ${ }^{2}$ Department of Earth and Environmental Sciences, University of Illinois at Chicago, 845 West Taylor Street, Chicago, Illinois 60607-7059, U.S.A. \\ ${ }^{3}$ Department of Geological Sciences, Binghamton University, P.O. Box 6000, Binghamton, New York 13902-6000, U.S.A.
}

\begin{abstract}
Prediction of sedimentary architecture for modeling of fluid flow in hydrocarbon reservoirs and aquifers is accomplished mainly using stochastic, structure-imitating models, because these can be conditioned to data from wells, seismic profiles, and outcrop analogs. Conditioning implies that modeled architecture fits all available observations. However, the sedimentary architecture simulated by such models is commonly unrealistic. Process-based (forward) models potentially provide more realistic prediction and understanding of sedimentary architecture, but these models are not widely used because conditioning to well, seismic, or outcrop data is considered to be very difficult. We show here that conditioning of process-based models to well data is possible in principle, using a 3D alluvial-architecture model as an example. This model considers the formation of alluvial deposits as a predominantly deterministic process, with a single channel belt moving by avulsion over an aggrading floodplain. However, the initial floodplain topography is simulated by a random field, thus yielding different model output for each run. Monte Carlo simulation was used to produce model realizations that fit five hypothetical vertical wells within predetermined tolerance bands. Such simulation allows calculation of the probability of occurrence of channel-belt deposits for each 3D cell in the 3D block of sediments generated by the model, as well as the probability distributions of volumes of channel-belt deposits and connectedness ratios. Adding more conditioning wells increases the precision of model predictions. Application of this approach in practice will require a major effort, particularly in overcoming the anticipated large amounts of computing time.
\end{abstract}

\section{INTRODUCTION}

Determination of the volume and quality of hydrocarbon reservoirs and aquifers, and development of fluid production and management strategies, requires understanding of the geometry, orientation, proportion, and spatial distribution (i.e., architecture) of the various sediment types present. Information derived from geophysical profiles, cores, well logs, and well-test data is rarely sufficient to provide comprehensive 3D description and understanding of hydrocarbon reservoirs or aquifers. Recourse must normally be made to outcrop analogs and depositional models. A common approach is to use outcrop analogs to provide supplementary data on sedimentary architecture, and to use stochastic models conditioned by subsurface data to distribute the architectural elements in 3D space (reviews by Bryant and Flint 1993; Koltermann and Gorelick 1996; North 1996; Anderson 1997).

Modeling approaches include structure-imitating methods and processbased methods. Structure-imitating models do not simulate processes of deposition. These models directly simulate the sedimentary architecture and generally include stochastic components. Methods used are indicator geostatistics (e.g., Journel 1983; Bierkens and Weerts 1994), simulated annealing (e.g., Deutsch and Cockerham 1994), Markov chains (e.g., Doveton 1994; Carle et al. 1998), and probabilistic rules defining the geometry and location of stratigraphic units, known as Boolean object models (e.g., Budding et al. 1992; Deutsch and Wang 1996; Hirst et al. 1993; Holden et al. 1998). An advantage of these models is that they are conditioned to observational data. However, adequate input parameters are difficult to obtain for simulating realistic depositional architectures (e.g., Tyler at al. 1994; Deutsch and Wang 1996; Holden et al. 1998).

Unlike the structure-imitating models mentioned above, three-dimensional process-based models, sometimes referred to as process-imitating models, simulate the sedimentary processes acting to produce a deposit (Koltermann and Gorelick 1996; Anderson 1997). Process-based models can be deterministic and/or stochastic, and empirical and/or theoretical. Examples of such models include random-walk sedimentation models of braided rivers (Webb 1994), models based on the fundamental equations of fluid flow and sediment transport (e.g., Bridge 1977, 1992; Tetzlaff and Harbaugh 1989; Stam 1996; Gross and Small 1998), and avulsion-related alluvial-architecture models (e.g., Bridge and Leeder 1979; Mackey and Bridge 1995; Heller and Paola 1996). Process-based models are forward models in the sense that they predict the nature of deposits given a set of initial starting parameters. It is not known a priori what the deposits will look like. Advantages of three-dimensional process-based models are that they can help provide genetic interpretations of deposits and can predict more realistic sedimentary architecture than structure-imitating (stochastic) models. A perceived disadvantage of three dimensional process-based models, however, is that it is difficult or impossible to make the simulated deposits fit (or be conditioned to) observational data in sufficient detail in three dimensions (Clemetsen et al. 1990; North 1996; Koltermann and Gorelick 1996; Anderson 1997). Therefore, process-based models have had limited application in quantitative simulation of the architecture of hydrocarbon reservoirs or aquifers, although recent studies have shown that simple, two-dimensional, sequence-stratigraphic models with simple process equations can be conditioned to well data (Bornholdt et al. 1999; Cross and Lessenger 1999). But such two-dimensional models have limited interpretive value in hydrocarbon reservoir characterization and geohydrology.

The advantages of structure-imitating and process based methods could be retained by combining them. One way of doing this would be the use of a range of outputs from process-based models to provide input for stochastic models. However, the view that three dimensional process-based models cannot be conditioned to observational data can be challenged.

It is demonstrated here that conditioning of three-dimensional processbased models to well data using an essentially trial-and-error approach is possible in principle, using an alluvial-architecture model as an example. The model, based on that of Mackey and Bridge (1995), considers the formation of alluvial deposits as a single channel belt moves by avulsion over an aggrading floodplain. The model is partly stochastic in the sense that it has a stochastic random field (initial floodplain topography) as input yielding a different model outcome (realization) for each run. Monte Carlo simulation is used to calculate the probability of occurrence of channelbelt deposits in each voxel (3D cell) of the 3D block of sediments generated by the model, as well as the probability distributions of volumes of channelbelt deposits and channel-belt connectedness ratios.

\section{MODEL CONCEPTS}

In this exploratory study, we use a slightly simplified version of the 3D alluvial-architecture model of Mackey and Bridge (1995). It was simplified to save computer time for conditioning the model to the wells. We developed the new model in the spatio-temporal modeling language that runs 
(A)
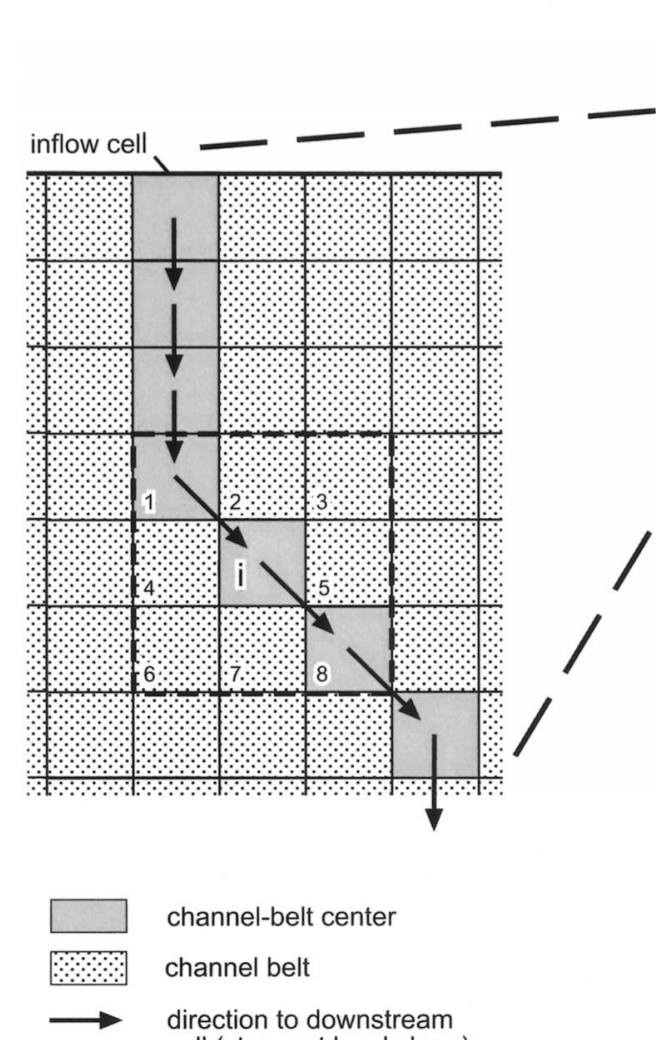

channel-belt center

channel belt

direction to downstream cell (steepest local slope)

$0150 \mathrm{~m}$
(B)

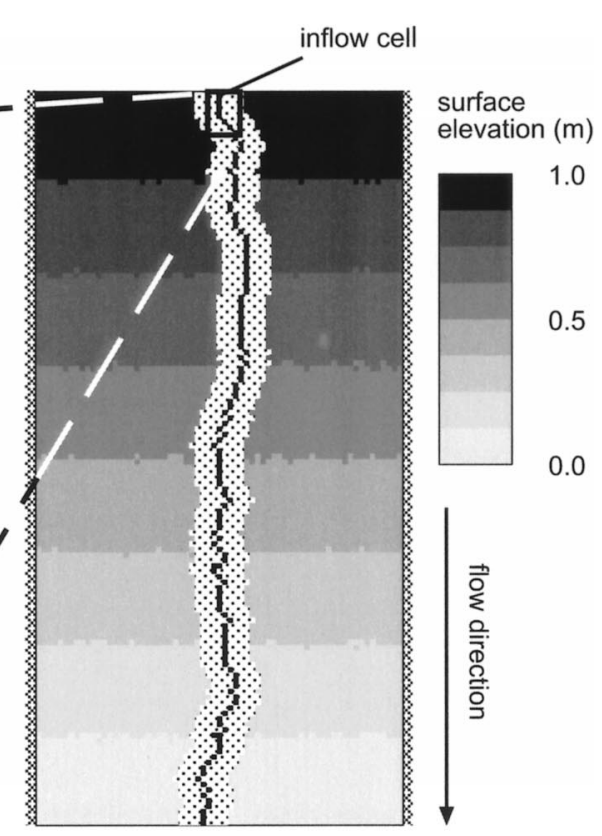

FIG. 1.-A) Calculation of channel-belt centerline that is the path in the direction of maximum floodplain slope. For cell $i$, the floodplain slope towards the 8 adjacent cells is calculated in order to determine the direction of maximum slope. B) Plan view of initial surface elevation $E(x, y, 0)(\mathrm{m})$, inflow cell, initial channel-belt centerline and initial channel belt. inside the PCRaster environmental modeling system (Wesseling et al. 1996). (PCRaster information and demonstration software including links to Gstat available at http://www.geog.uu.nl/pcraster.) Stochastic simulations are performed with Gstat (Pebesma and Wesseling 1998). The model starts by calculating the initial floodplain topography and the initial geometry and location of the channel belt. Then, the model calculates for each time step representing the period between avulsions: (1) channel-belt and overbank aggradation (thickness, age, and type of deposited sediment, i.e., either channel-belt or overbank deposit) and new surface topography; and (2) channel-belt avulsion location and new channel-belt location (including erosion of previous deposits by channel-belt incision).

\section{Initial Floodplain Topography}

The rectangular modeling area has a down-valley length $L(\mathrm{~m})$ and width $W(\mathrm{~m})$. It is discretized by square raster cells with constant cell length $C$ (m) and cell center coordinates $x, y(\mathrm{~m}$; origin at the bottom left corner of the modeling area). The initial floodplain surface has a constant downvalley slope plus uncorrelated random noise representing local variation in elevation. The initial floodplain topography is the only stochastic input to the model. For each cell, the surface elevation at the start of the model run is

$$
E(x, y, 0)=S \cdot y+e(x, y)
$$

with:

$E(x, y, 0)$ surface elevation (m) at point $x, y$ at time $t=0$ (yr),

$S \quad$ down-valley slope $(-)$,

$y \quad$ distance of the cell center from the downstream end of the modeling area $(\mathrm{m})$, $e(x, y) \quad$ stochastic field: spatially uncorrelated random noise with variance $\sigma$ and zero mean.

\section{Channel-Belt Geometry and Initial Location}

Throughout the model run, a single channel belt is active on the floodplain. Unaggraded channel-belt dimensions are defined by the bankfull channel depth $d(\mathrm{~m})$ and channel-belt width $w(\mathrm{~m})$, both constant in time. The inflow location of the channel-belt center is at the upstream center cell (i.e., inflow cell) throughout a model run. The initial channel-belt location on the floodplain is determined by first defining the cells representing the downstream path of the channel belt center following the local direction of maximum floodplain slope, using the 8-point pour algorithm (Moore 1996; Burrough and McDonnell 1998). Each channel-belt center cell $i$ leads to a channel-belt center cell that is one of the $n=1 \ldots 8$ adjacent cells following the maximum downstream slope (Fig. 1A). Local closed depressions are removed using the algorithm of Van Deursen (1995). The initial channel belt consists of the cells with a distance less than $w / 2$ normal to this centerline (Fig. 1B).

\section{Channel-Belt and Overbank Aggradation}

The aggradation rate in the channel belt $(a, \mathrm{~m} / \mathrm{yr})$ is constant in space and time. Overbank aggradation rate decreases with distance from the channel-belt edge. For each point $x, y$ and time step $t$, the aggradation rate in the overbank area $A(x, y, t)(\mathrm{m} / \mathrm{yr})$ is:

$$
A(x, y, t)=a c+a(1-c) e^{-D(x, y, t) / b}
$$

where: 


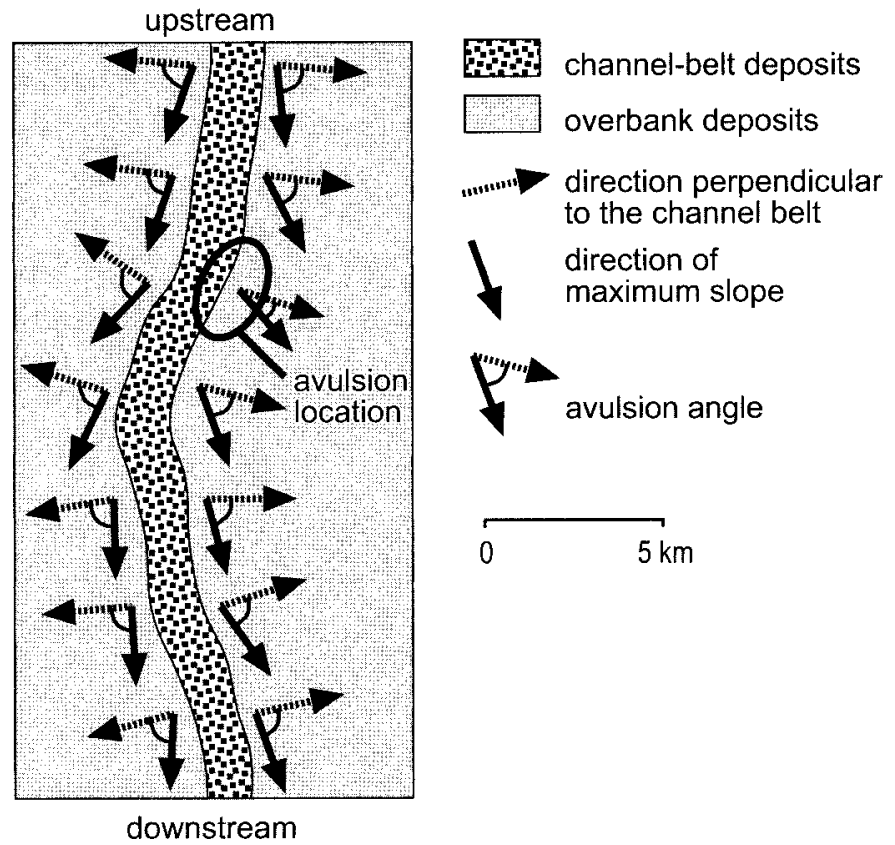

FIG. 2.-Determination of the location of the channel-belt avulsion.

a channel-belt aggradation rate $(\mathrm{m} / \mathrm{yr})$,

$c$ theoretical aggradation rate at infinite distance from the channel belt, expressed as a fraction of $a(-)$,

$D(x, y, t)$ distance to the channel-belt edge at time step $t(\mathrm{~m})$,

$b \quad$ dimensionless aggradation exponent (-).

Mackey and Bridge (1995) did not include the $c$ value in the equation for overbank aggradation rate. Equation (2) allows definition of aggradation rates that approach a value much greater than zero at large distances away from the channel belt that is not possible if $c$ is omitted. If $c$ is set to zero, the equation is equivalent to Mackey and Bridge's equation (1995), when $D$ is converted to their dimensionless distance from the channel-belt edge.

For each time period between avulsions, the total thickness of aggraded sediment is stored by the computer model. This deposit is labeled with its age and sediment type (channel-belt deposit or overbank deposit). Erosion of formerly deposited strata occurs only as a result of incision of new channel belts. In the interest of simplicity, compaction of sediment is not included in this model (cf. Bridge and Leeder 1979; Mackey and Bridge 1995).

\section{Avulsion}

Avulsion is the process whereby the channel belt shifts abruptly from one location to another on the floodplain. In the interest of model simplicity, avulsion occurs at a constant time interval $T$ (yr). Concepts of calculation of the avulsion location correspond with Mackey and Bridge (1995), but the algorithms used are slightly different. The floodplain surface morphology at the edge of the channel belt determines the avulsion location (Fig. 2). The direction of maximum floodplain slope at the edge of an unaggraded channel belt will be approximately parallel to the active channel belt, resulting in a low probability of avulsion. Because the aggradation rate of the channel belt is greater than that of the overbank area, however, an alluvial ridge develops, and the direction of maximum floodplain slope may locally change from parallel to nearly perpendicular to the edge of an aggraded channel belt. This situation will lead to a high probability for an avulsion to occur (cf. Heller and Paola 1996; Slingerland and Smith 1998). This principle is represented in the model with the following algorithm. For each cell immediately neighboring the channel belt the avulsion angle
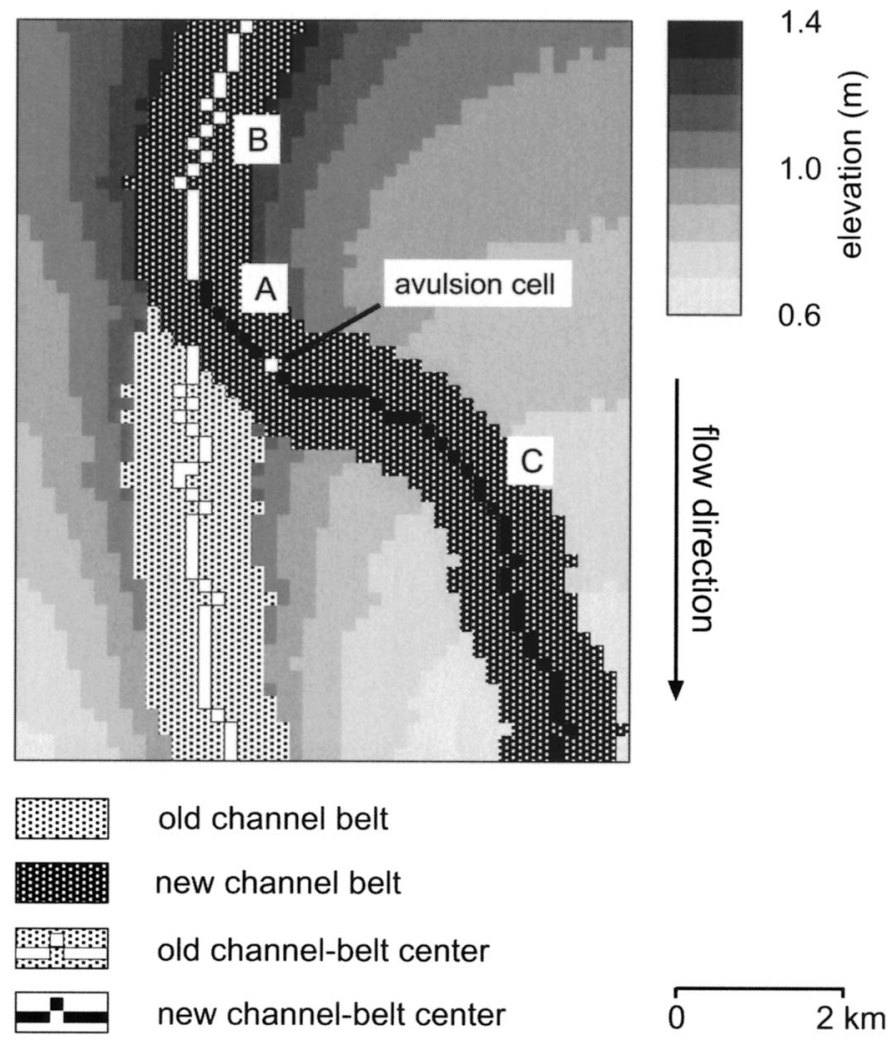

FIG. 3.-Calculation of new channel-belt center and new channel belt following an avulsion. Letters A, B, and C refer to explanation in text.

(A)

(B)

\section{$\begin{array}{ll}\text { WELL } & \text { MODEL } \\ \text { LOG } & \text { OUTPUT }\end{array}$}
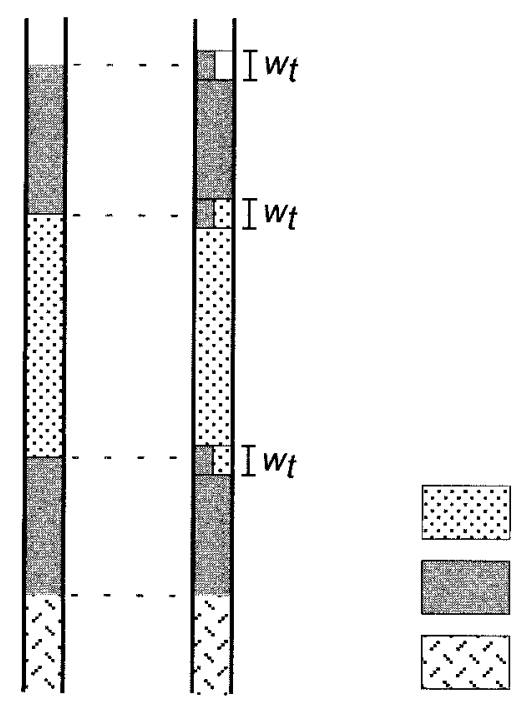

channel-belt deposits

overbank deposits

substratum

FIg. 4.-Evaluation of the objective function for each well. A) Well log and B) model output for conditioned result with tolerance bands $w_{t}$. 
(A)

(B)
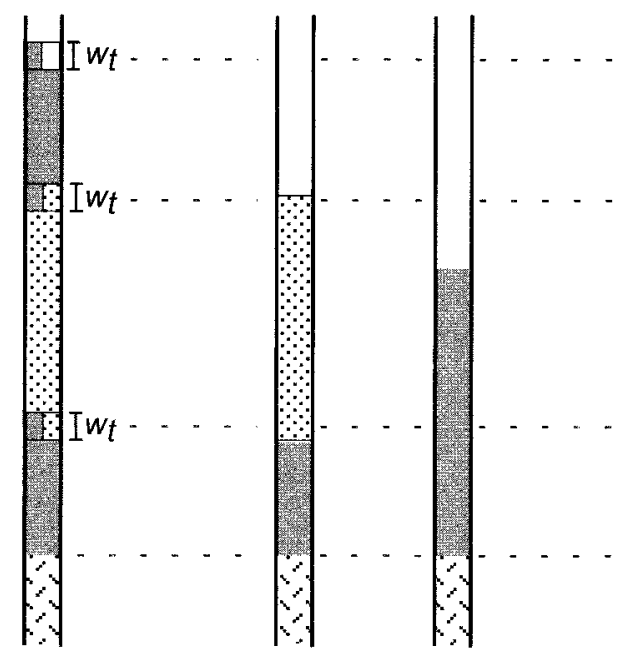

model outputs at $\mathrm{t}=\mathrm{i}$

well $\log$
(C)

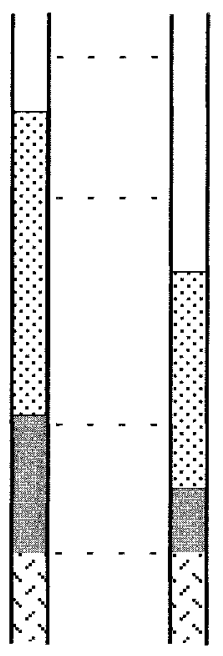

channel-belt deposits

overbank deposits

substratum

overbank or channel-belt deposits (tolerance bands)

FIG. 5.-Evaluation of the directive function for each well. A) Well log with tolerance bands with width $w_{t}$. B) Model output at the well location for $t=i$ without directive function error: runs possibly resulting in conditioned model result at $t=$ end. C) Model output at the well location for $t=i$ with directive function error: runs that will not result in conditioned model result at $t=e n d$.

$\alpha$ is calculated by $\alpha=|\beta-\gamma|$, with $\beta$, the azimuth of direction of maximum floodplain slope (algorithm of Horn 1981, also described in Burrough and McDonnell 1998), and $\gamma$, the azimuth of direction perpendicular to the channel-belt edge.

The avulsion location is the cell with the lowest avulsion angle $(\alpha)$ immediately adjacent to the channel belt (Fig. 2). The lowest avulsion angle is equivalent to the highest value of Mackey and Bridge's (1995) slope ratio. The centerline of the new channel belt is determined as: (1) the set of cells that connect the avulsion cell with the center of the former channel belt (upstream path, A in Fig. 3); (2) the center of the former channel belt upstream of this connecting set of cells (B in Fig. 3); and (3) the downstream path from the avulsion cell over the locus of maximum floodplain slope (C in Fig. 3) calculated with the 8-point pour algorithm also applied for the initial channel belt. The new channel belt consists of cells with a distance of less than $w / 2$ normal to this centerline.

\section{CONDITIONING TO WELL DATA}

Our model is stochastic only in the sense that the initial floodplain topography is represented in part by a random field, causing the first channel belt to be at a different location and elevation for each model run. As a result, the entire alluvial succession will be different for each run because the behavior of the model is determined by antecedent conditions. In fact, the probability that one model run will result in an outcome that agrees with well data is very low. The trial-and-error method for producing pro-

TABLE 1.-Model parameter values for the case study.

\begin{tabular}{|c|c|c|}
\hline Symbol & Value & Description \\
\hline$L$ & 20100 & down-valley floodplain length (m) \\
\hline$W$ & 10050 & cross-valley floodplain width (m) \\
\hline$C$ & 150 & cell length (m) \\
\hline$S$ & $5 \cdot 10^{-5}$ & down-valley slope $(-)$ \\
\hline$\sigma$ & $3 \cdot 10^{-3}$ & $\begin{array}{l}\text { variance of spatially uncorrelated random variation for } \\
\text { initial floodplain surface }(\mathrm{m})\end{array}$ \\
\hline$d$ & 10 & bankfull channel depth (m) \\
\hline$w$ & 1200 & channel-belt width (m) \\
\hline$a$ & $2 \cdot 10^{-3}$ & channel-belt aggradation rate $(\mathrm{m} / \mathrm{yr})$ \\
\hline$c$ & 0.5 & $\begin{array}{l}\text { theoretical deposition rate at infinite distance from channel } \\
\text { belt, fraction of } a(-)\end{array}$ \\
\hline$b$ & $1 \cdot 10^{3}$ & overbank-aggradation exponent $(-)$ \\
\hline$T$ & 400 & time interval between avulsions (yr) \\
\hline$w_{t}$ & 0.6 & width of tolerance bands (m) \\
\hline
\end{tabular}

cess-based model outcomes that agree with well data (well-conditioned output) is described below.

\section{Stochastic Model with Output Conditioned to Well Data}

The stochastic model resulting in an output conditioned to well data is

$$
\begin{gathered}
U(x, y, z)=\mathrm{g}\left(E(x, y, 0), d_{1}(x, y, z), \ldots, d_{m}(x, y, z)\right) \text { and } \\
\mathrm{f}(U(x, y, z), \mathbf{w})=0
\end{gathered}
$$

where

$$
\begin{array}{ll}
\mathrm{g}(\cdot) & \begin{array}{l}
\text { process-based alluvial-architecture model, } \\
\text { input random field: initial topography of the } \\
\text { floodplain surface, }
\end{array} \\
d_{1}(x, y, z), \ldots, d_{m}(x, y, z) & \begin{array}{l}
\text { deterministic input fields for the alluvial archi- } \\
\text { tecture model, }
\end{array} \\
U(x, y, z) & \begin{array}{l}
\text { output random field: well-conditioned alluvial } \\
\text { architecture, }
\end{array} \\
\mathrm{objective} \text { function for well-conditioned output, } \\
\text { well data. }
\end{array}
$$

The only input random field is $E(x, y, 0)$, the randomly varying initial floodplain elevation with random variation. All other parameters of the model are assigned deterministic values. The output random field is $U$ $(x, y, z)$, which is the 3D block of sediment generated by the stochastic model at the end of the model run. In this block, each voxel has a probability of containing channel-belt deposits. The Boolean objective function $\mathrm{f}(\cdot)$ is a function of $U(x, y, z)$ and the well data $\mathbf{w}$, giving an error of zero or one. If the error is zero, the outcome of the process-based model fits the well data within predetermined limits. If the error is one, the model outcome does not adequately fit the well data. The objective function is described in the next section.

The stochastic model derives the distributions (or parameters describing these) of the random field $U(x, y, z)$ from: (1) the distribution of the input random field $E(x, y, z)$ and the deterministic inputs $d_{1}(x, y, z), \ldots, d_{m}(x$, $y, z)$; (2) the process-based model $\mathrm{g}(\cdot)$; (3) the well data w; and (4) the objective function $\mathrm{f}(\cdot)$. The Monte Carlo simulation approach solves this in two steps (Hammersley and Handscomb 1979; Heuvelink 1998):

\section{Step (1)}

Repeat $\mathrm{K}$ times (lower case letters represent realizations):

(a) Generate a realization of the initial floodplain elevation: input random field $e(x, y, z)$.

(b) With this realization and deterministic input fields $d_{1}(x, y, z), \ldots$, $d_{m}(x, y, z)$, run $\mathrm{g}(\cdot)$ and compute the outcome $u(x, y, z)$ of the processbased model.

(c) With the model outcome $u(x, y, z)$ and well data $\mathbf{w}$, calculate the 
(A)

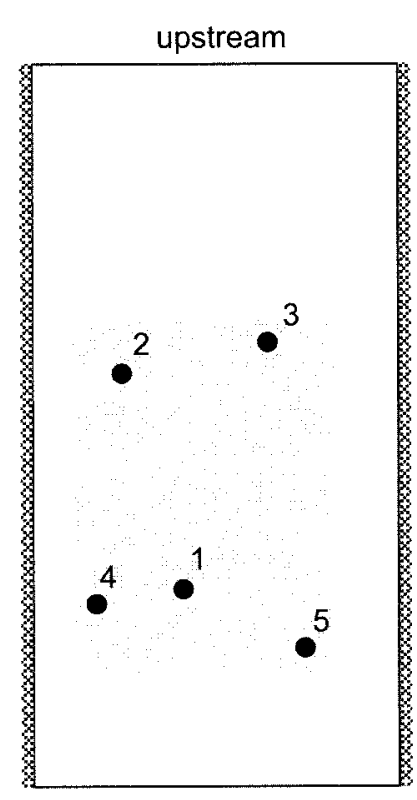

downstream
(B)

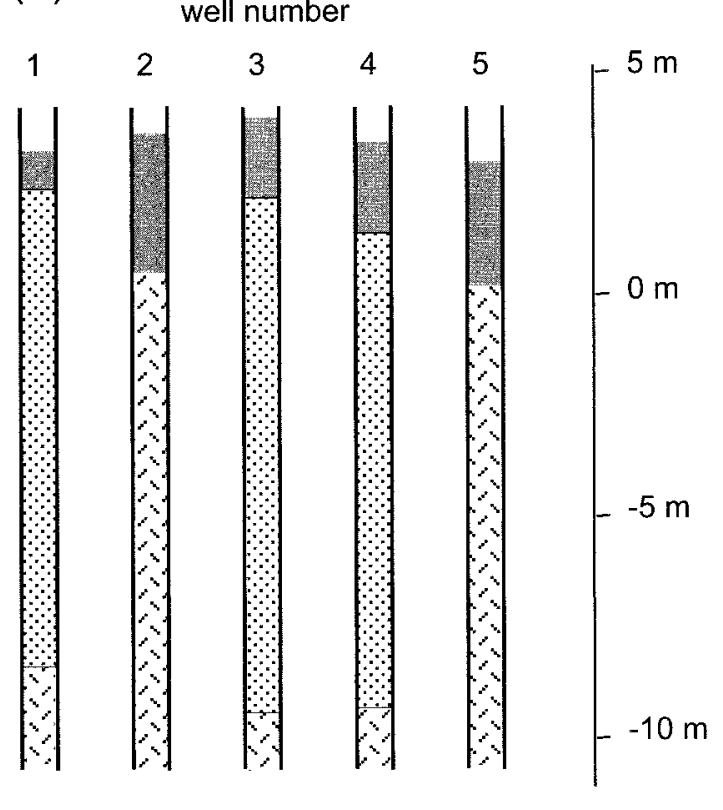

\begin{tabular}{|c|c|c|c|}
\hline & well area & $\Leftrightarrow$ & channel-belt deposits \\
\hline & well with number & E & overbank deposits \\
\hline 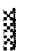 & floodplain edge & $\therefore<$ & substratum \\
\hline 0 & $5 \mathrm{~km}$ & & \\
\hline
\end{tabular}

Fig. 6.-Case study well data set. A) Model area with the location of the wells and $\mathbf{B}$ ) well logs. Well area is used for calculation of volume of channel-belt deposits and connectedness ratio. Origin of vertical axis corresponds to original topography (substratum) at downstream edge of the floodplain. Note that substantial amounts of substratum have been eroded at wells 1,3 , and 4. error of the objective function $\mathrm{f}(\cdot)$. If the error is 1 , the outcome of the process-based model does not fit the well data and start again at (a); otherwise continue to (d).

(d) Store the model outcome $u(x, y, z) . \mathrm{N}$ is the number of outcomes of the process-based model that resulted in well-conditioned output.

\section{Step (2)}

Compute sample statistics (e.g., mean, variance, skewness, channel-belt connectedness ratio, volume of channel belt deposits) from the $\mathrm{N}$ wellconditioned outcomes $u_{1 . . N}(x, y, z)$ of the process-based model.

\section{Objective Function}

The role of the objective function is to select the realizations of the process-based model that fit the well data within prescribed limits. These well-conditioned realizations are used for computing the sample statistics of the conditioned outcomes of the process-based model (e.g., channel-belt connectedness ratio). Running the model without the restrictions defined by the objective function results in a model output that does not fit the well data.

For each loop in the Monte Carlo simulation, the objective function is defined as

$$
\mathrm{f}\left(u, w_{1}, \ldots, w_{n}\right) \begin{cases}=0, & \text { if the generated alluvial succession } u \\ & \text { fits all well } \log w_{1 \ldots n}, \\ =1, & \text { if the generated alluvail sucession } u \\ & \text { does not fit one or more well logs } w_{1 \ldots n}\end{cases}
$$

In the current model, we use vertical well logs with positions and thickness of the channel-belt and overbank deposits. For each well, the well log is compared with the alluvial succession generated by the process-based model at the vertical that contains the well. Figure 4 shows how the objective function is evaluated for each well. Figure $4 \mathrm{~A}$ shows the well log. Because exact conditioning is extremely difficult, tolerance bands with vertical length $w_{t}$ (Fig. 4B) are defined at the boundary between the channel-belt deposits and overbank deposits, and at the top of the well log (top surface). The succession at the well location is said to fit the well data if the model output matches the strata in the well log within the tolerance bands, typically $0.1-1 \mathrm{~m}$.

\section{Reducing Computing Time with a Directive Function}

In step (1) of the Monte Carlo simulation, only a small number of runs of the process-based model give output that matches well data, and a lot of computing time is needed because the process-based model has to be run thousands of times. For this reason, a directive function is included to decrease run times. This function is applied in step (1b) of the Monte Carlo simulation. The principle is that, while running the process-based model 
$t=0$

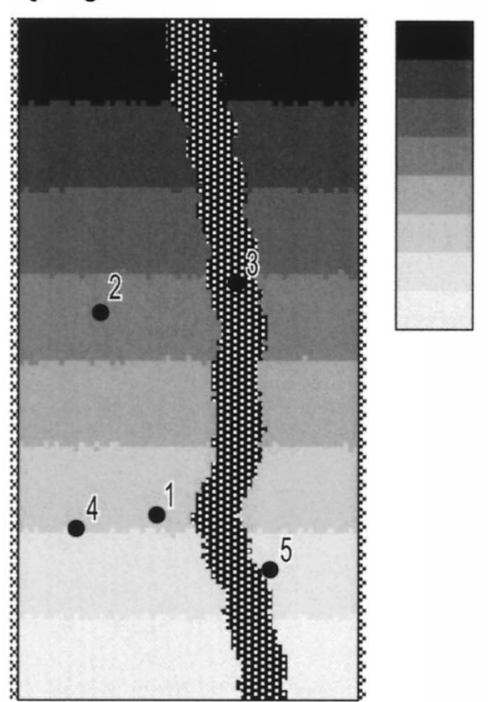

$1.0 \mathrm{~m}$.

0.5
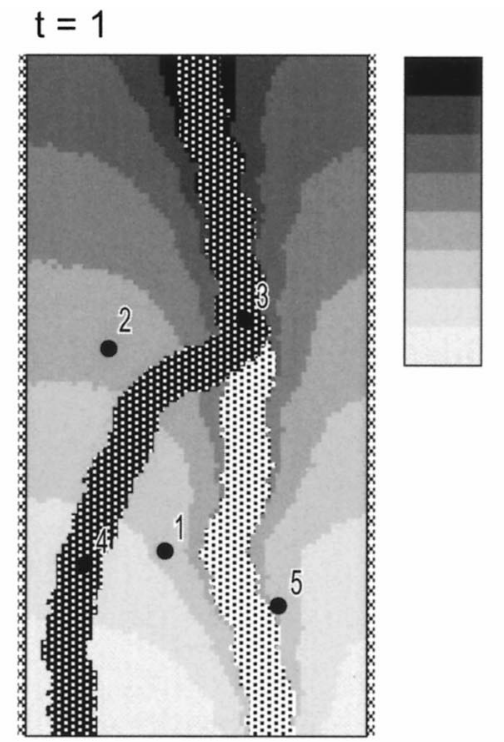

$1.8 \mathrm{~m}$.

1.1
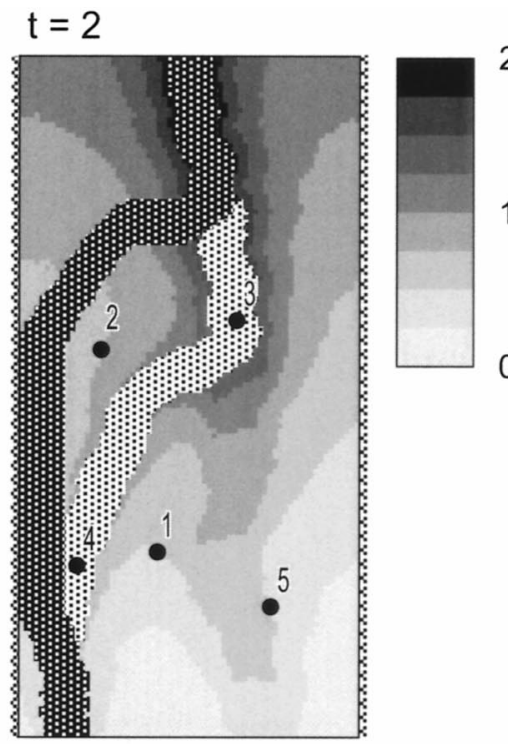

$2.6 \mathrm{~m}$.

1.7

0.8 $t=4$

$3.4 \mathrm{~m}$.

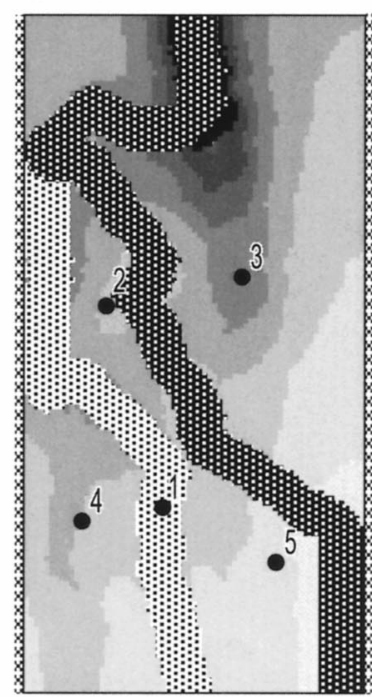

well

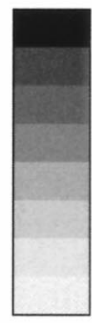

$4.2 \mathrm{~m}$.

$t=5$
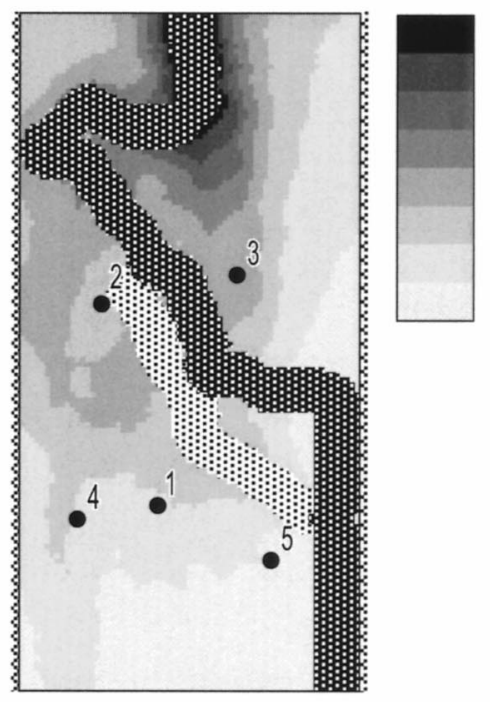

$5.0 \mathrm{~m}$.

3.7

2.4
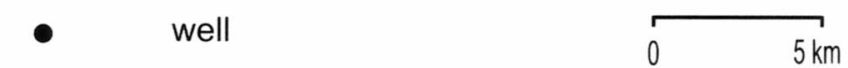

\section{old channel belt}

FIg. 7.-Evolution in time of conditioned model run, including initial situation $(t=0)$ and five successive time steps (each timestep represents 400 yr). Each map shows the position of the old and new channel belt, and surface topography $(\mathrm{m})$ at the end of the time step, i.e., at the moment of the avulsion. The new channel belt corresponds with the old channel belt for the next time step.

forward in time, for each $t=i$ the alluvial succession $u(t=i)$ is compared with the well data $w_{1}, \ldots, w_{n}$. If the alluvial succession for $t=i$ deviates from the well data in such a way that the model outcome will not be conditioned at the end of the model run, the run is interrupted and a new loop $\mathrm{K}$ is started by generating a new input random field (step 1a). Otherwise the process run is continued.

The directive function uses the property of the process-based model that channel-belt deposits cannot be replaced by overbank deposits, because erosion of the floodplain occurs only as a result of channel-belt incision. A run of the process-based model that predicts channel-belt deposits in a well log at time step $t$ where the well log contains overbank deposits cannot give a conditioned result, and the run of the process-based model is interrupted. As in the objective function, this comparison is done only for the well $\log$ outside the tolerance bands (Fig. 5). Within the tolerance bands, the sediment type predicted by the model may deviate from the well log.

\section{CASE STUDY}

An example of an application of the approach, using model parameters given in Table 1, is now described. Figure 6 gives the hypothetical well 


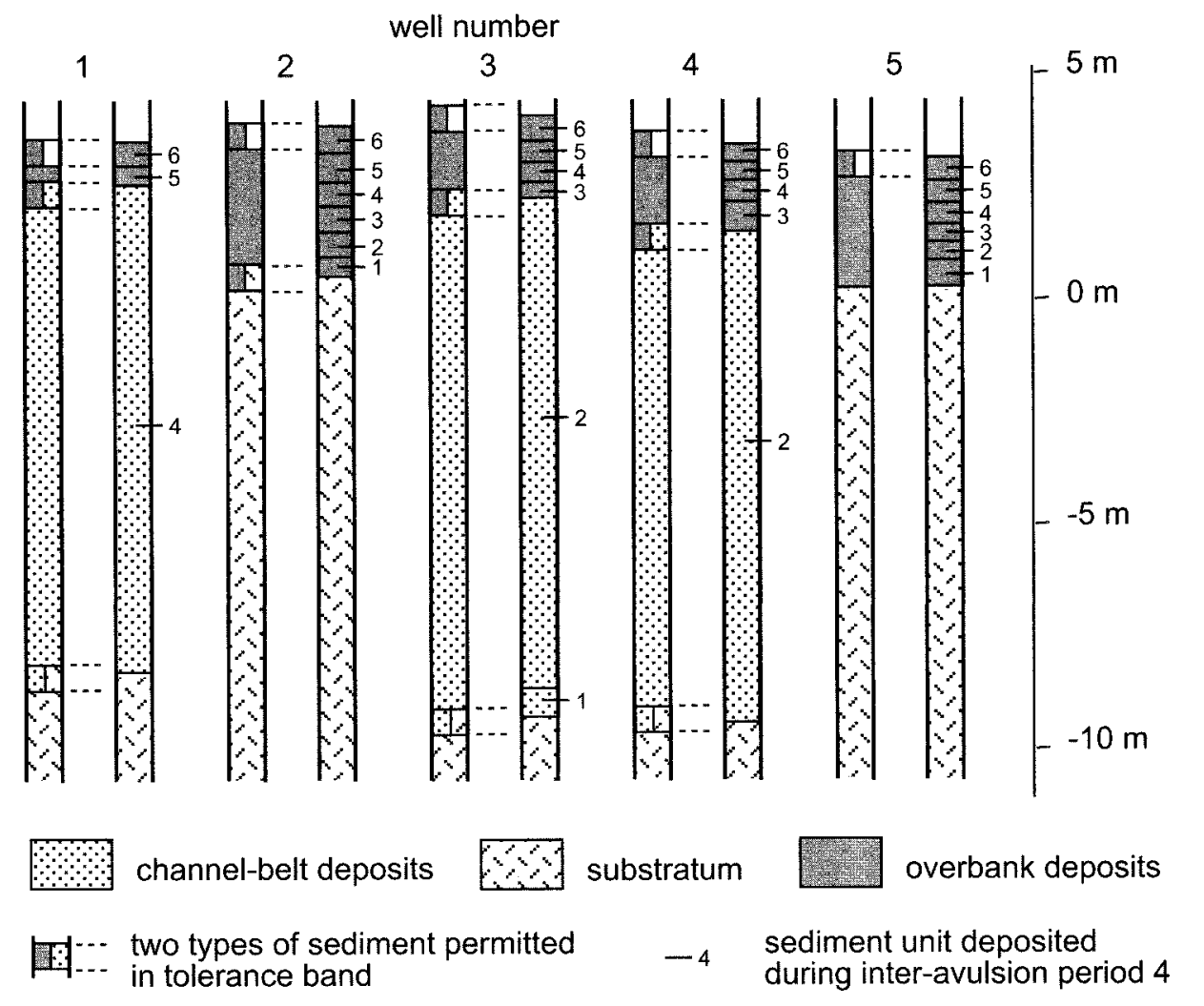

FIG. 8.-Conditioning to well data of the model run in Figure 7. For each well number the left column represents the well log with tolerance bands; the right column represents model output. Numbers to the right of the wells refer to interavulsion periods (i.e., time steps in Fig. 7). Substratum is material below initial floodplain surface at $t=0$. data set used for conditioning. Model test runs demonstrated that a minimum value of $0.6 \mathrm{~m}$ is necessary for the width of the tolerance band. A further decrease in $w_{t}$ resulted in unacceptably large computer run times to arrive at 50 realizations that fit the wells, needed for the stochastic model. Figure 7 gives the evolution in time of the floodplain for one run of the process-based model with the simulated deposits fitting the five wells. The initial floodplain at $t=0$ shows a channel belt that is slightly curved as a result of the random noise included in the initial floodplain topography. The decrease in deposition rate with distance from the channel belt is represented in the topography at the end of a time step: an alluvial ridge is formed at the location of the channel belt. As a result of this alluvial ridge, an avulsion occurs resulting in a new channel-belt location for the next time step. The maps show that the new channel belt for each time step follows the lowest topography downstream of the avulsion location. The simulated succession at the well sites matches the stratigraphy in the well logs within the tolerance bands (Fig. 8). Figure 9 gives the 3D alluvial architecture resulting from the model run of Figure 7.

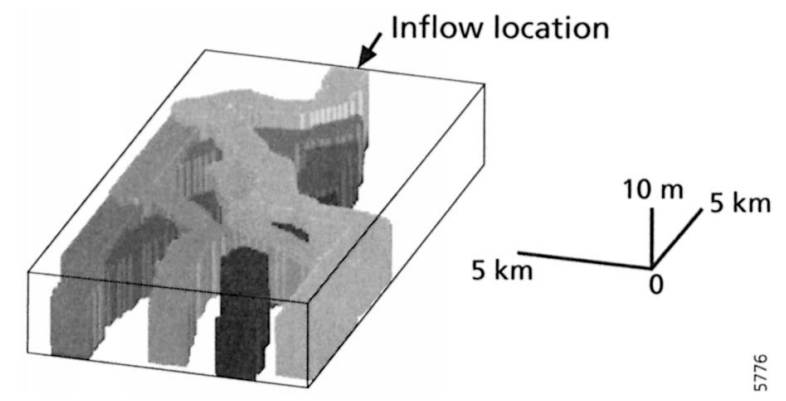

FIG. 9.-3D alluvial architecture resulting from the realization of the model in Figure 7. Only channel-belt deposits are shown.

\section{Effect of Number of Conditioning Wells on Model Output}

In order to evaluate the effect of the number of conditioning wells on the model outcome, the stochastic model was run without conditioning and conditioned to different numbers of wells. Figure 10 shows the stochastic outcomes of alluvial architecture for three scenarios, based on 50 realizations for each scenario ( $\mathrm{N}=50$ in the Monte Carlo simulation procedure).

Without conditioning (Fig. 10A), probabilities of greater than 0.8 for the occurrence of channel-belt deposits occur at the edges of the floodplain and close to the channel-belt inflow location. High probabilities at the edges of the floodplain are related to the decrease in deposition rate (hence floodplain elevation) with distance from the channel belt. An initial channel belt at the center of the floodplain results in the lowest deposition rate and elevation at the edge of the floodplain. Thus, subsequent channel belts tend to move towards these low areas (Fig. 7). The area directly downstream of the inflow location has high probabilities because all channel belts originate in this zone. Between these high probability areas, values are typically $0.3-$ 0.5 and show little spatial structure.

Addition of conditioning well data (Fig. 10B, C) results in spatial heterogeneity occurring in the central part of the floodplain in addition to the pattern observed for the unconditioned run. Volumes with low and high probabilities for the occurrence of channel-belt deposits occur immediately adjacent to each other. The scenario conditioned to wells 1 and 2 (Fig. $10 \mathrm{~B})$ results in an extensive volume with high probabilities of channel-belt occurrence upstream and downstream of well 1 . Well 2 containing only overbank deposits results in low channel-belt probabilities near the well. The probability field for the scenario where all wells are used for conditioning is strongly determined by the five well logs (Fig. 10C).

\section{Number of Well Logs and Estimation Precision}

Total volume of channel belt deposits $\left(\mathrm{m}^{3}\right)$ and areal (2D) connectedness ratio were calculated within the area of the well data (Fig. 6). Areal con- 

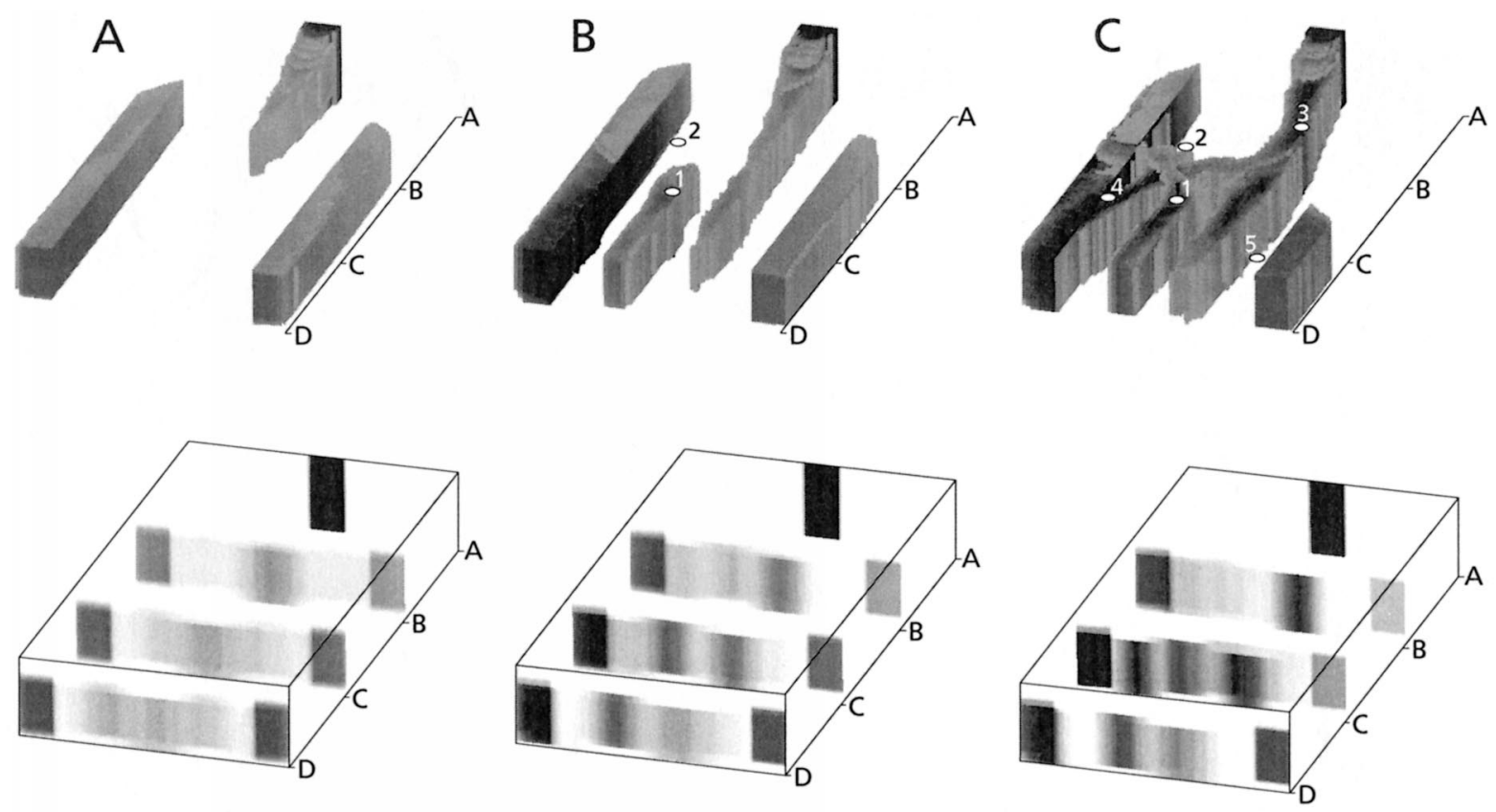

\section{o well location}
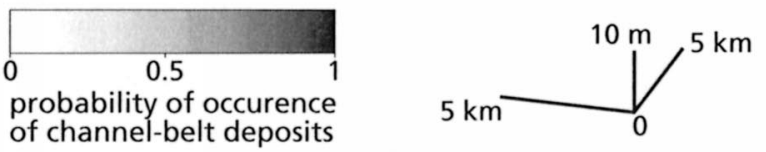

FIG. 10.-3D images of probability of occurrence of channel-belt deposits. Top diagrams show volumes with probability $>0.8$. Bottom diagrams are transects through the 3D block; grayscale represents probability of occurrence of channel-belt deposits. A) Model unconditioned to wells. B) model conditioned to wells 1 and 2. C) model conditioned to wells $1-5$.

nectedness ratio is the sum for all channel belts of the total horizontal area of contact with another one, divided by the total horizontal area of all channel belts (Fig. 11). Results for total volume of channel-belt deposits are reported here instead of net-to-gross ratio (channel-deposit proportion), which can also be calculated. Net-to-gross ratios are not discussed because the thickness of the simulated deposit is too small to enable realistic comparison with real world successions.

Probability density distributions of total volume of channel-belt deposits and the areal connectedness ratios are unimodal (Fig. 12). Average total volume of channel-belt deposits is between $4.0 \cdot 10^{8}$ and $4.8 \cdot 10^{8} \mathrm{~m}^{3}$. Average connectedness ratios for the scenarios with different numbers of wells are between 0.4 and 0.5 . There is no clear trend in these values with increasing number of wells.

Prediction precision, however, does increase with increasing number of conditioning wells, as shown by a decrease in coefficients of variation and an increase in the volume fraction of the 3D block that is predicted with high precision. The coefficient of variation of total volume of channel-belt deposits decreases from 0.18 to 0.13 (Fig. 13A). Similarly, coefficients of variation for connectedness ratio decrease from 0.45 with no conditioning wells to 0.21 when five conditioning wells are used (Fig. 13B). Addition of more well data also increases the precision of the prediction of the $3 \mathrm{D}$ block of alluvial architecture. The volume fraction of this block that is predicted by the model with a high probability $(>0.9)$ of occurrence of either channel-belt or overbank deposits increases with increasing number of wells (Fig. 14). If there is no conditioning to well data, a volume fraction of only 0.08 is predicted by the model as channel-belt deposits or overbank deposits with a probability of occurrence greater than 0.9 . With five wells, this fraction is 0.15 .

\section{DISCUSSION AND CONCLUSIONS}

The goal of this study is to show that it is possible in principle to condition process-based models to observational data. The example given here does not prove the applicability of the process-based model to real-world problems, because the model and the hypothetical well data were relatively simple. Fitting of the model to the well data using Monte Carlo simulation required much computer time. For example, 5000 realizations took five days running time on a $200 \mathrm{MHz}$ Linux machine to arrive at 50 realizations that fit five wells. As a result, success of the method with real-world problems depends on future decrease of model run times. It is expected that model run times can be reduced by development of faster computers, optimizing the computer program (e.g., improve the directive function), providing key input parameters, and application of optimization algorithms for finding model outcomes that fit well data, such as genetic algorithms (Bornholdt et al. 1999). However, model run times will be increased as the process-based models become more complicated.

The computing time required depends on the probability that one run of the process-based model will fit the well data. Figure 15A shows the probability distribution $U_{a u}$ of the alluvial architecture generated by the unconditioned model and the range $r$ of all possible alluvial architectures that fit the observational data. For illustrative purposes, $U_{a u}$ is assumed to be normal here, although other probability distributions would be possible. The probability $p$ that one run of the process-based model fits the well data is the area under the curve of $U_{a u}$ for alluvial architectures $r$. The probability $p$ depends on several factors. Increasing the number of wells for conditioning decreases the range of alluvial stratigraphies $r$ that will fit all wells, resulting in a smaller value for $p$ (Fig. 15B). Increasing the width of the 
(A)

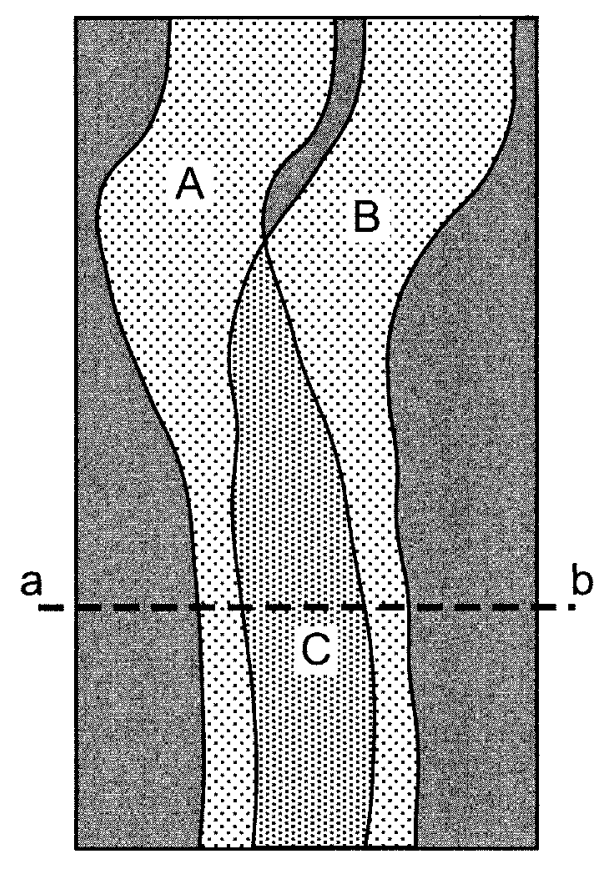

horizontal contact between channel belts

overbank deposits channel belt, no vertical contact

(B) a

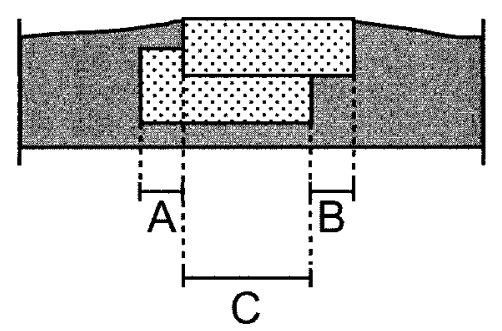

channel-belt deposits

overbank deposits
FIg. 11.-Method of calculation of areal channel-belt connectedness ratio, A) plan view, B) cross section. A, B, and C represent areas $\left(\mathrm{m}^{2}\right)$. Horizontal contact between channel belts exists in area $\mathrm{C}$. Channel-belt connectedness ratio is $2 C /(A+B+2 C)$.
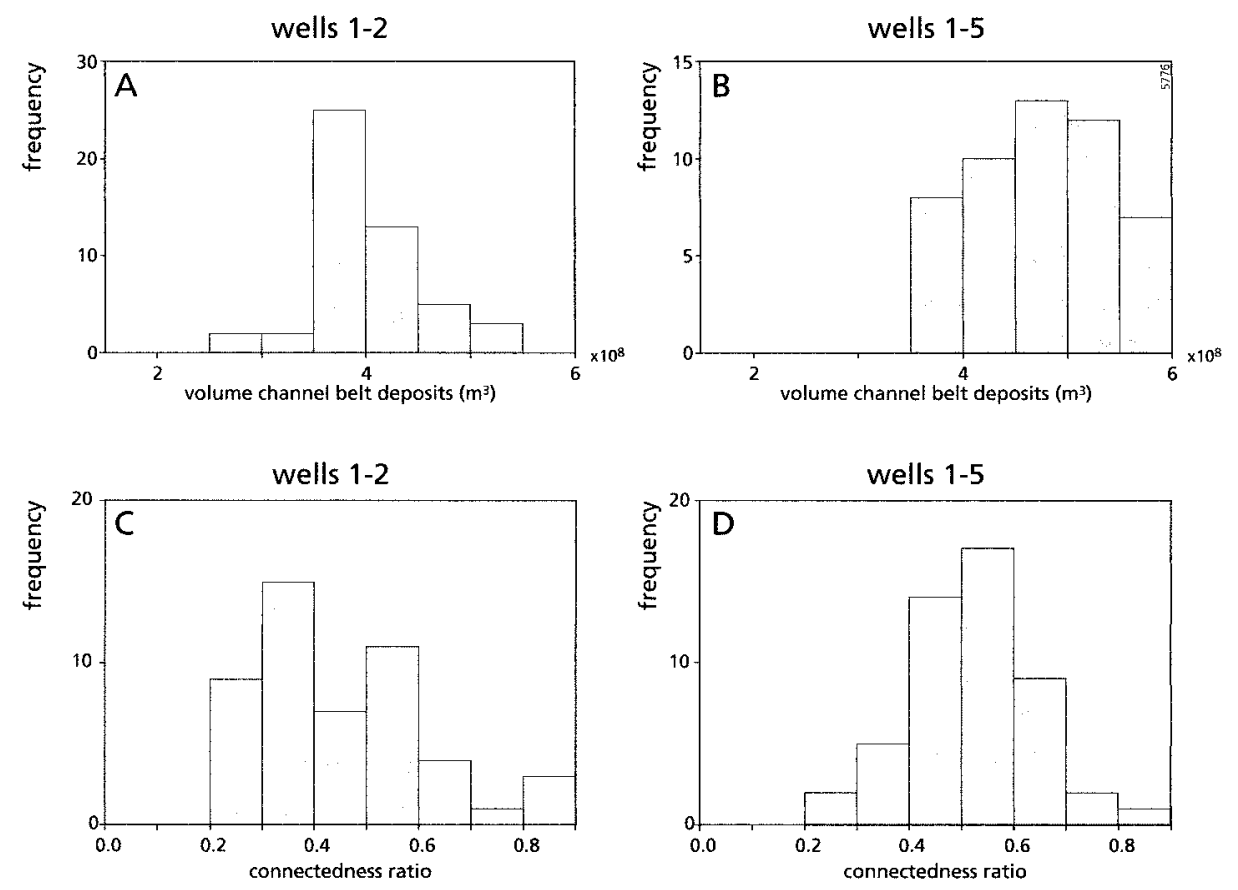

FIG. 12.-Probability density distributions for (A, B) total volume of channel-belt deposits in the well area and $(C, D)$ channel-belt connectedness ratios in the well area. A, C) Model conditioned to wells 1 and 2; $\mathbf{B}, \mathbf{D}$ ) model conditioned to all the wells $1-5$. 
(A)

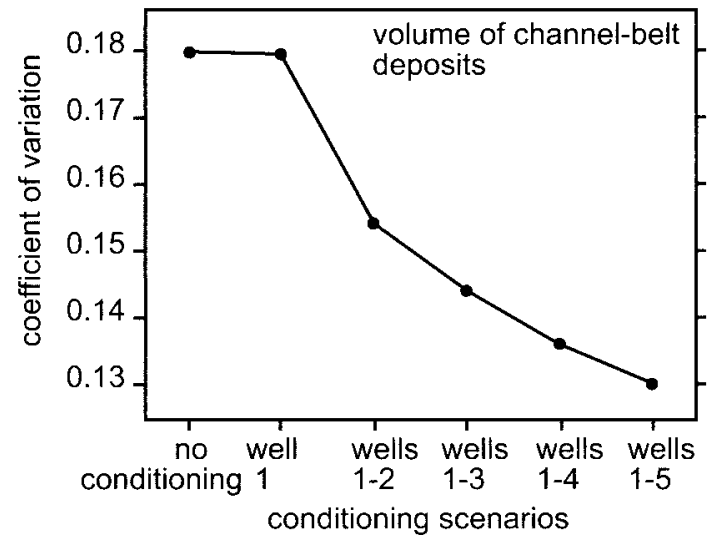

(B)

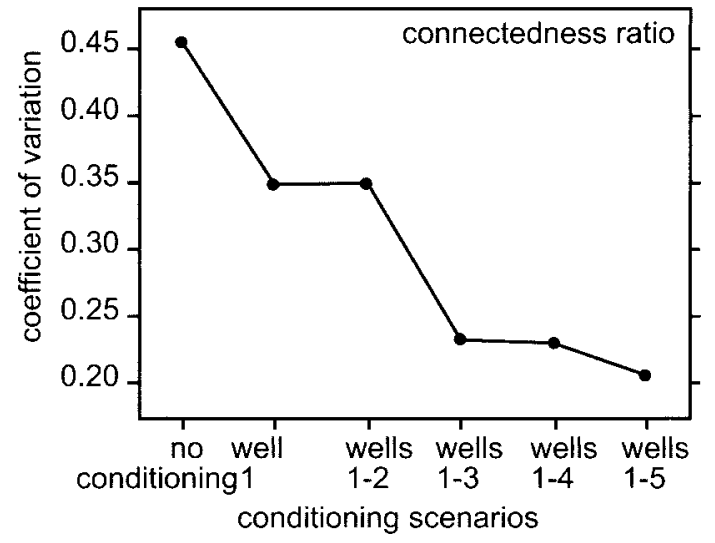

FIg. 13.-Coefficients of variation (standard deviation divided by mean value) for A) total volume of channel-belt deposits and B) connectedness ratio. Different wellconditioning scenarios on $x$ axis.

(A)

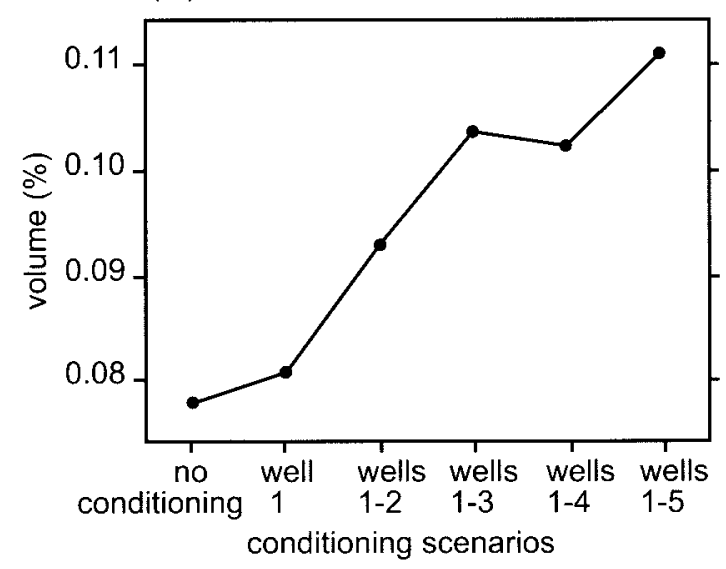

(C)

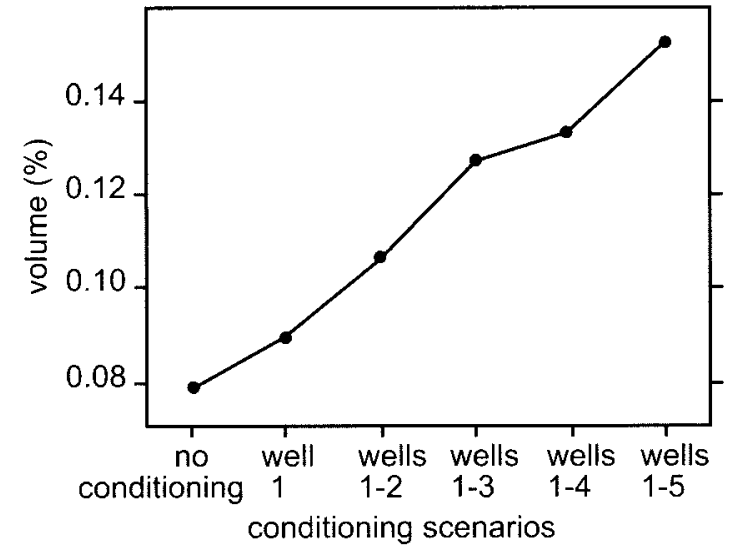

(B)

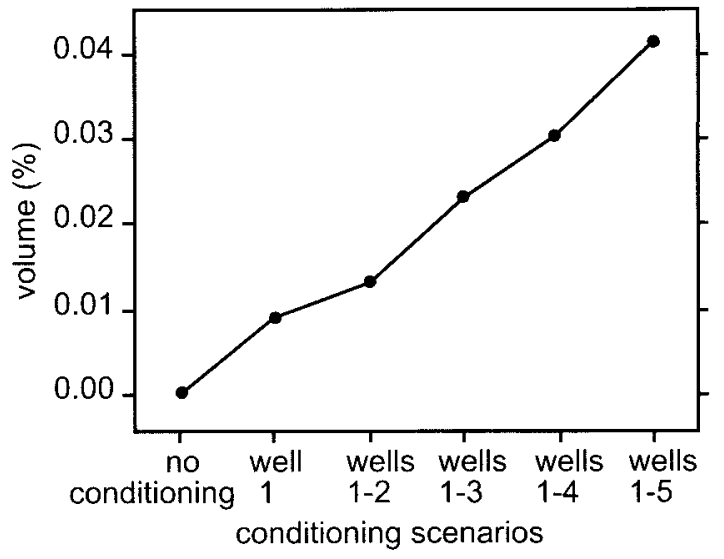

FIG. 14.-Volume fraction in the well area that is A) classified as containing no channel-belt deposits with a probability $>0.9$; B) classified as containing channel-belt deposits with a probability $>0.9$; and $\mathbf{C}$ ) total volume classified with a probability $>0.9$ (sum of values in graph A and B). Different scenarios of conditioning to well data on the $x$ axis. 

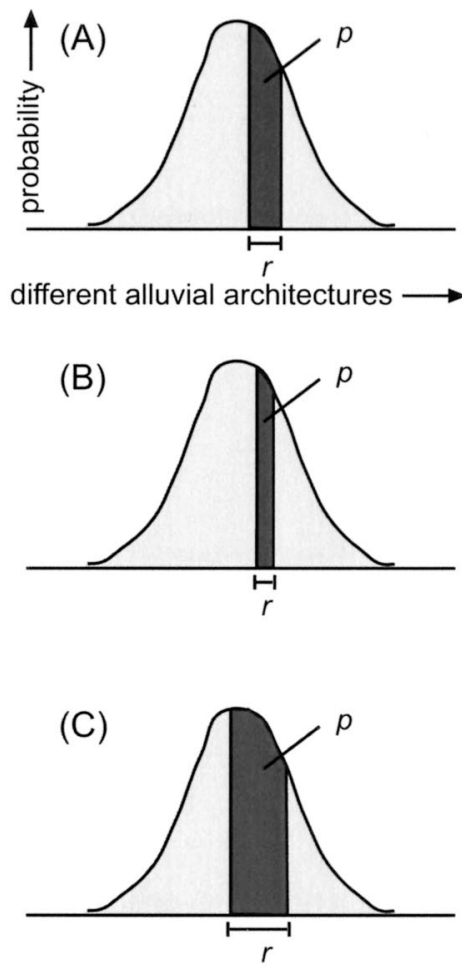
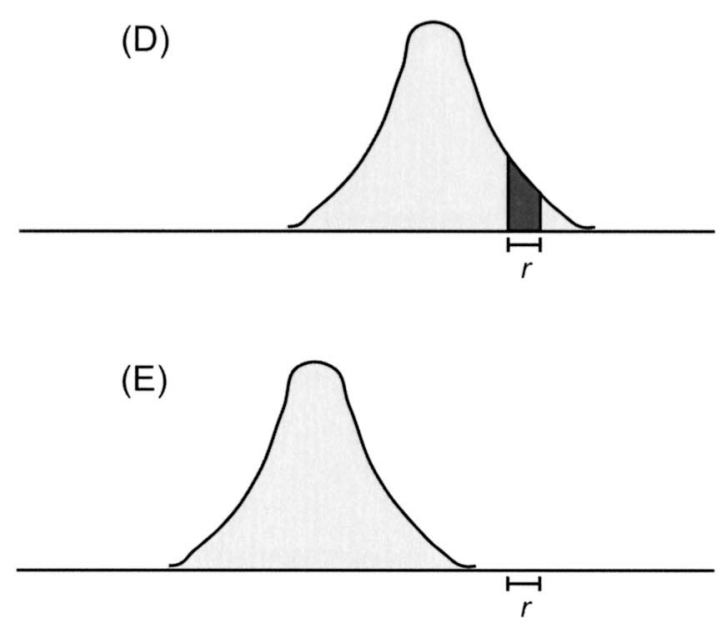

(E)

(F)

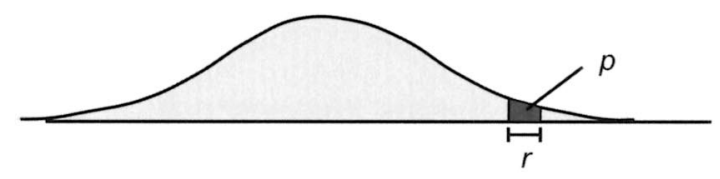

FIG. 15.-Schematic probability density distribution $\left(U_{a w}\right.$ area under the curve is 1$)$ of alluvial architecture for unconditioned model run and range of possible alluvial architectures conditioned to well data $r$. Each location on the $x$ axis represents a different alluvial architecture. The $x$ axis is the same for all figures. The area under the curve of $U_{a u}$ for $r$ is the probability $p$ for a conditioned model outcome. A) Standard curve. Effects of B) larger number of well data, C) larger tolerance bands, D, E) incorrect model structure or model parameters, F) higher degree of variability in the stochastic input. tolerance bands $w_{t}$ in the objective function increases the range of alluvial stratigraphies $r$ that are regarded as being conditioned, resulting in a higher value for $p$ (Fig. 15C). If the process-based model or its input parameters are incorrect, $r$ will be at one of the tails of the distribution of $U_{a u}$ and $p$ values will be very small (Fig. 15D) or even zero (Fig. 15E). This can be solved by increasing the variability of the stochastic input of the model, resulting in a wider distribution of $U_{a w}$, but $p$ values will be relatively low (Fig. 15F).

Successful conditioning of a process-based model depends on the amount of soft information that is available in addition to hard observational data. Soft information may come from seismic profiles and ancient or modern analogs. Conditioning to seismic data and analog data is expected to be possible with some changes in the objective and directive functions. Soft data may include paleoflow direction, channel-belt geometry, aggradation rates, floodplain width, and the presence of synsedimentary faults. If these data are not available, a process-based model can still be used by using stochastic variables for these input parameters. In the example given here, it is assumed (in the interest of simplicity) that these parameters were known except for the initial floodplain elevation, which was represented as a stochastic variable. Adding more stochastic inputs to process-based models would be a worthwhile extension to the approach of sedimentary architecture modeling described here.

Under the assumptions of a correct model structure and input, the Monte Carlo method applied here gives model outputs that are true probability distributions. For each voxel, the probability of occurrence and the connectedness of channel-belt deposits is known. This is an advantage compared to some stochastic modeling studies in which only one or a few realizations are given. Another advantage of Monte Carlo simulation is the possibility of deriving a relationship between the number of observational data (i.e., wells) and the precision of the predicted architecture.

The quality of prediction of alluvial architecture using process-based models depends strongly on the quality of the model used. Current knowledge of alluvial processes allows considerable improvement of the model presented here. Such development would be worthwhile in view of the potential of this method of fitting process-based models to observational data. Furthermore, the potential use of process-based models to provide input to purely stochastic models would also require further development of process-based models.

Process-based models conditioned to observational data could potentially be used in other depositional environments such as coastlines, marine shelves, and submarine fans. The method also has potential for application at larger scales (such as sequence-stratigraphic models) and smaller scales (such as crevasse-splay models).

\section{ACKNOWLEDGMENTS}

We thank Cees Wesseling (PCRaster Environmental Software), Kor de Jong, and Edzer Pebesma (Utrecht University) for programming and providing the Gstat and PCRaster software used for the numerical simulations in this paper; and Jaap Kwadijk for providing the initial impetus for sedimentary architecture modeling in PCRaster. We are also grateful to Marc Bierkens, Peter Burrough, and Kees Geel, as well as journal referees Colin North, Paul Heller, and Jeffrey Yarus for helpful comments on earlier drafts.

\section{REFERENCES}

Anderson, M.P., 1997, Characterization of geological heterogeneity, in Dagan, G., and Neuman, S.P., eds., Subsurface Flow and Transport: A Stochastic Approach: Cambridge, U.K., Cambridge University Press, p. 23-43.

Bierkens, M.F.P., AND WeERTs, H.J.T., 1994, Application of indicator simulation to modelling the lithological properties of a complex confining layer: Geoderma, v. 62, p. 265-284.

Bornholdt, S., Nordlund, U., and Westphal, H. 1999, Inverse stratigraphic modeling using genetic algorithms, in Harbaugh, J.W., Watney, W.L., Rankey, E.C., Slingerland, R., Goldstein, R.H., and Franseen, E.K., eds., Numerical Experiments in Stratigraphy: Recent Advances in Stratigraphic and Sedimentologic Computer Simulations, SEPM, Special Publications 62 , p. 85-90.

BRIDGE, J.S., 1977, Flow, bed topography, grain size and sedimentary structure in open channel bends: a three-dimensional model: Earth Surface Processes, v. 2, p. 401-416.

BRIDGE, J.S., 1992, A revised model for water flow, sediment transport, bed topography, and grain size sorting in natural river bends: Water Resources Research, v. 28, p. 999-1013.

BRIDGE, J.S., AND LeEDER, M.R., 1979, A simulation model of alluvial stratigraphy: Sedimentology, v. 26, p. 617-644.

BRYANT, I.D., AND FLINT, S., 1993, Quantitative clastic reservoir geological modeling: problems 
and perspectives, in Flint, S. and Bryant, I.D., eds., The Geological Modelling of Hydrocarbon Reservoirs and Outcrop Analogues: International Association of Sedimentologists, Special Publication 15, p. 3-20.

Budding, M.C., PaArdekam, A.H.M., and Van Rossem, S.J., 1992, 3D connectivity and architecture in sandstone reservoirs: SPE Technical Paper 22342, presented at SPE International Meeting on Petroleum Engineering, Beijing, China, 24-27 March.

Burrough, P.A., AND McDonnell, R.A., 1998, Principles of Geographical Information Systems: Oxford, U.K., Oxford University Press, 333 p.

Carle, S.F., Labolle, E.M., Weissmann, G.S., Van Brocklin, D., and Fogg, G.E., 1998, Conditional simulation of hydrofacies architecture: a transition probability/Markov approach, in Fraser, G.S., and Davis, J.M., eds., Hydrogeologic Models of Sedimentary Aquifers: SEPM, Concepts in Hydrogeology and Environmental Geology, no. 1, p. 147-170.

Clemetsen, R., Hurst, A.R., Knarud, R., and Omre, H., 1990, A computer program for evaluation of fluvial reservoirs, in Buller, A.T., Berg, E., Hjelmeland, O., Kleppe, J., Torsaeter, O., and Aasen, J.O., eds., North Sea Oil and Gas Reservoirs II: London, Graham \& Trotman, p. 373-385.

Cross, T.A., ANd Lessenger, M.A., 1999, Construction and application of a stratigraphic inverse model, in Harbaugh, J.W., Watney, W.L., Rankey, E.C., Slingerland, R., Goldstein, R.H., and Franseen, E.K., eds., Numerical Experiments in Stratigraphy: Recent Advances in Stratigraphic and Sedimentologic Computer Simulations, SEPM, Special Publications 62, p. 69 83.

Deutsch, C., AND CocKerham, P., 1994, Practical considerations in the application of simulated annealing to stochastic simulation: Mathematical Geology, v. 26, p. 67-82.

Deutsch, C.V., AND WANG, L., 1996, Hierarchical object-based stochastic modeling of fluvial reservoirs: Mathematical Geology, v. 28, p. 857-880.

Doveton, J.H., 1994, Theory and applications of vertical variability measures from Markov Chain analysis, in Yarus, J.M., and Chambers, R.L., eds., Stochastic Modeling and Geostatistics: American Association of Petroleum Geologists, Computer Applications in Geology, no. 3, p. 55-64.

Gross, L.J., and Small, M.J., 1998, River and floodplain process simulation for subsurface characterization: Water Resources Research, v. 34, p. 2365-2376.

Hammersley, J.M., and Handscomb, D.C., 1979, Monte Carlo Methods: London, Chapman \& Hall, $178 \mathrm{p}$.

Heller, P.L., and Paola, C., 1996, Downstream changes in alluvial architecture: an exploration of controls on channel-stacking patterns: Journal of Sedimentary Research, v. 66, p. 297306.

Heuvelink, G.B.M., 1998, Error Propagation in Environmental Modelling with GIS: London, Taylor \& Francis, 127 p.

Hirst, J.P.P., Blackstock, C.R., And Tyson, S., 1993, Stochastic modelling of fluvial sandstone bodies, in Flint, S.S., and Bryant, I.D., eds., The Geological Modelling of Hydrocarbon
Reservoirs and Outcrop Analogues: International Association of Sedimentologists, Special Publication 15, p. 237-252.

Holden, L., Hauge, R., Skare, Ø., and Skorstad, A., 1998, Modeling of fluvial reservoirs with object models: Mathematical Geology, v. 30, p. 473-496.

HoRN, B.K.P, 1981, Hill shading and the reflectance map: Institute of Electrical and Electronics Engineering, Proceedings, v. 69, p. 14-47.

JouRnel, A.G., 1983, Nonparametric estimation of spatial distributions: Mathematical Geology, v. 15 , p. $445-468$.

Koltermann, C.E., AND GoRelick, S.M., 1996, Heterogeneity in sedimentary deposits: A review of structure-imitating, process-imitating, and descriptive approaches: Water Resources Research, v. 32, p. 2617-2658.

MACKEY, S.D., AND BRIDGE, J.S., 1995, Three-dimensional model of alluvial stratigraphy: theory and application: Journal of Sedimentary Research, v. B65, p. 7-31.

Moore, I.D., 1996, Hydrological Modeling and GIS, in Goodchild, M.F., Steyaert, L.T., Parks, B.O., Johnston, C., Maidment, D., Crane, M., and Glendinning, S., eds., GIS and Environmental Modeling: Progress and Research Issues: Fort Collins, Colorado, GIS World Books, p. $143-148$.

NoRTH, C.P., 1996, The prediction and modelling of subsurface fluvial stratigraphy, in Carling, P.A., and Dawson, M.R., eds., Advances in Fluvial Dynamics and Stratigraphy: New York, John Wiley \& Sons Ltd, p. 395-508.

Pebesma, E., and Wesseling, C.G., 1998, Gstat: a program for geostatistical modelling, prediction and simulation: Computers \& Geosciences, v. 24, p. 17-31.

Slingerland, R., AND Smith, N., 1998, Necessary conditions for a meandering-river avulsion: Geology, v. 26, p. 435-438.

Stam, J.M.T., 1996, Migration and growth of aeolian bedforms: Mathematical Geology, v. 28 , p. $519-536$.

Tetzlaff, D.M., and Harbaugh, J.W., 1989, Simulating Clastic Sedimentation: New York, Van Nostrand Reinhold, 202 p.

Tyler, K., Henriquez, A., And Svanes, T., 1994, Modeling heterogeneities in fluvial domains: a review of the influence on production profiles, in Yarus, J.M., and Chambers, R.L., eds., Stochastic Modeling and Geostatistics: American Association of Petroleum Geologists, Computer Applications in Geology, no. 3, p. 77-89.

Van Deursen, W.P.A., 1995, Geographical Information Systems and Dynamic Models: Nederlands Geografische Studies, v. 190, 198 p.

WeBB, E.K., 1994, Simulating the three-dimensional distribution of sediment units in braidedstream deposits: Journal of Sedimentary Research, v. B64, p. 219-231.

Wesseling, C.G., Karssenberg, D., van Deursen, W.P.A., and Burrough, P.A., 1996, Integrating dynamic environmental models in GIS: the development of a Dynamic Modelling language: Transactions in GIS, v. 1, p. 40-48.

Received 25 October 2000; accepted 15 May 2001. 